\title{
The efficacy and safety of Tocilizumab in adults with refractory systemic onset JIA
}

\author{
G Deslypere $^{1 *}$, C Wouters $^{2}$, J Joly ${ }^{1}, \mathrm{R}$ Westhovens ${ }^{1}$ \\ From 18th Pediatric Rheumatology European Society (PReS) Congress \\ Bruges, Belgium. 14-18 September 2011
}

\section{Objective}

Systemic-onset JIA (so-JIA) is often persisting into adulthood and can be refractory to treatment including biologicals. We report on efficacy and safety of Tocilizumab in adults with persistent active so-JIA in a retrospective single center descriptive cohort study.

\section{Patients and methods}

Disease activity scores (DAS-CRP), ESR and CRP were measured just before and at 1- 6- and 12 months of Tocilizumab treatment in all adults with refractory soJIA at our University Hospital. Adverse events were recorded.

\section{Results}

Eight patients (5 women, 3 men) with a median age of $27,5 \mathrm{yr}$ and median disease duration of $16 \mathrm{yr}$ were treated. All previously failed Methotrexate, other classical DMARD's, 7/8 also failed on one or more biologicals (mostly TNF blockers, Anakinra in 1). Median HAQ before starting Tocilizumab was 1.25 (0.75-2.13). Tocilizumab dose was $8 \mathrm{mg} / \mathrm{kg} / \mathrm{month}$, except for 1 patient receiving $6 \mathrm{mg} / \mathrm{kg} / 2$ weeks. The median DAS-CRP decreased from 5,10(1.6-5.3) $(\mathrm{n}=6)$ at start to 2,25(1.32.9) $(\mathrm{n}=6)$ after six months $(\mathrm{p}=0,046)$. At 12 months, median DAS-CRP was 1,9(1.5-6.1) $(\mathrm{n}=3)$. Median ESR/ CRP decreased from 35(15-87) $(\mathrm{n}=6) / 69,2(9.1-292.6) \mathrm{mg} / \mathrm{l}$ $(\mathrm{n}=8)$ at start to

$2(1-7) / 1,2(0.6-1.4) \mathrm{mg} / \mathrm{l}(\mathrm{n}=7)$ at six months $(\mathrm{p}=0,028 /$ $0,018)$. At 1 year median ESR/CRP were $3,5(1-13)(n=4) /$ $0,6(0.6-23.1) \mathrm{mg} / \mathrm{l}(\mathrm{n}=5)$. A decrease/complete stop of steroids was observed in 6 patients. Atypical rash was seen in one patient, EBV-induced MAS occurred in 1 patient after 7 yrs of Tocilizumab.

* Correspondence: griet.deslypere@uzleuven.be

${ }^{1}$ Rheumatology, University Hospital KU Leuven, Belgium

Full list of author information is available at the end of the article

\section{Conclusion}

Our report on young adults with persistingly active soJIA treated with Tocilizumab shows a fast, steep and persistent decrease in disease activity up to at least 1 year, demonstrating the efficacy of IL6-receptor antagonism also in patients with long-standing refractory soJIA.

\section{Author details}

${ }^{1}$ Rheumatology, University Hospital KU Leuven, Belgium. ${ }^{2}$ Pediatric

Rheumatology, University Hospital KU Leuven, Belgium.

Published: 14 September 2011

doi:10.1186/1546-0096-9-S1-P137

Cite this article as: Deslypere et al:: The efficacy and safety of

Tocilizumab in adults with refractory systemic onset JIA. Pediatric Rheumatology 2011 9(Suppl 1):P137.

Submit your next manuscript to BioMed Central and take full advantage of:

- Convenient online submission

- Thorough peer review

- No space constraints or color figure charges

- Immediate publication on acceptance

- Inclusion in PubMed, CAS, Scopus and Google Scholar

- Research which is freely available for redistribution

\section{(Ciomed Central}

(C) 2011 Deslypere et al; licensee BioMed Central Ltd. This is an open access article distributed under the terms of the Creative Commons Attribution License (http://creativecommons.org/licenses/by/2.0), which permits unrestricted use, distribution, and reproduction in any medium, provided the original work is properly cited. 